\title{
The Impact of Technology on School Library Media Centers in Two Florida School Districts
}

\author{
KAY BISHOP \\ University of South Florida, \\ Tampa, Florida 33620-7800 \\ kbishop@chumal.cas.usf.edu
}

\begin{abstract}
In the last two decades technology has had a tremendous impact on school library media centers and personnel. The purposes of this study are to investigate the effects of technology on (1) school library media programs, (2) collections, (3) jobs of media personnel, and (4) student learning in media centers, and to determine if media staffing influences such effects. Twentythree media personnel in two Florida school districts with different media staffing procedures were administered open-ended questionnaires. In both districts technology had positive effects on provision of information resources in many formats to accommodate a variety of student learning styles, management of the media center, and creation of enthusiasm and interest in learning. It appeared that differences in district staffing and funding affected feelings about the impact of technology on jobs and the media collection.
\end{abstract}

\section{INTRODUCTION}

There can be no doubt that technology has made a huge impact on global society, on institutions in all parts of the world, and on people's jobs. The school library media center is certainly no exception to this impact. In the last two decades school library media specialists have seen numerous new technologies (videos, computer software programs, CD-ROMs, DVDs, and Internet) added to the information formats already present in their library media centers. Additionally, they have been called upon to not only learn how to use new equipment (video cameras, laser disk players, digital cameras, closed circuit television distribution systems, computers, scanners, and all kinds of telecommunication systems), but also to teach students and faculty how to operate such equipment. This has presented many challenges (as well as positive contributions) to library media center programs, the management and use of collections, the responsibilities of library media specialists, and to the student learning that takes place in the library media centers. This study was undertaken to investigate how technology has influenced these areas of school librarianship, and to determine if differences in staffing of school library media centers affects the impact of technology.

While many studies have focused on possible positive benefits of the use of technology on improved student achievement, higher test scores, and student enthusiasm, most of these studies have concentrated on the classroom use of technology. Very few studies specifically address the impact of technology in school library media centers. 
A review of the literature on this topic revealed a small number of studies that can contribute to the understanding of how technology has affected school library media centers and/or school library media personnel. In her study to determine how high school media specialists spend their time, Everhart (1990) found that media specialists with automated circulation systems spent their time differently than those without automated systems. Media specialists with automated systems spent more time developing educational programs and using technology. No differences were found in the time spent by media specialists with or without automated systems in the following areas: administration, instruction, selection, processing, clerical, providing access, reference, organizations, or personal time.

Zimmerman's study (1992) replicated an earlier study by Weeks (1982) that measured the attitudes of New York state school library media specialists toward library networking and technology. Zimmerman added the effect of the length of experience with networks to her study. Findings indicated positive support for networking, which was not affected by length of participation in the network. The respondents expressed dissatisfaction in areas of technical, financial, and human support. The researcher concluded that this suggested a gap between attitudes and practice.

Perceptions of Texas school library media specialists' use of Internet in their schools was the focus of Bruns' (1997) study in which the researcher found media specialists believed their training improved their students' library research studies and improved student learning. The survey respondents did not feel that their Internet use increased global collegiality, nor did they think that having an acceptable use policy ensured students' access to the Internet.

A paper describing the impact of lottery funding for technology in Georgia includes a short discussion of the concentration of technology in media centers and the resulting demands on media specialists' time. In this study it was reported that despite the creation of a technology specialist position for K-12 schools in Georgia, many media specialists' responsibilities tended to converge with the technology specialists, in part because the roles and responsibilities of the technology specialists were not clearly defined (Meghabghab \& Price, 1997).

A still more recent study measured the information technology available in school library media centers and the attitude of the media specialists towards that technology. Powell (1998) found that personal and professional characteristics, including age and perceived level of expertise, were closely associated with attitudes, while years of experience, educational background, and source of technology training did not associate with the attitudes of the school library media specialists.

Although not as formalized as the other studies discussed, the editors of School Librarian's Workshop surveyed readers and through anecdotal comments reported on how technology has added responsibilities to school media specialists' time, affected their budgets, made an impact on students' accessibility of electronic formats, and affected media center collections (Balancing act-part I, 1999; Balancing act-part II, 1999). 


\section{RESEARCH QUESTIONS}

In the fall of 1999 the researcher met informally with school library media specialists in School District A, which is located in Florida, and asked them what topics of research would be most helpful to them. The school media specialists unanimously agreed that determining the impact of technology on their jobs and their library media centers would provide both the media specialists and district personnel with beneficial information. Thus, the topic of this engaged community research study was selected.

The researcher developed four broad research questions dealing with the impact of technology on media centers: (1) How has technology affected school library media programs? (2) How has technology affected the school library media collections? (3) How has technology affected the jobs of school library media personnel? (4) How has technology affected student learning in school library media centers? The researcher was also interested in a secondary question-Does the method of staffing in a media center influence the impact of technology on school media centers? Thus, a second school district in Florida, with a different type of media staffing, was included in the study.

\section{METHODOLOGY}

In both school districts the terms "media specialist" and "media center" are generally used, rather than "school library media specialist" and "school library media center." Therefore, the shorter terms will be employed in the following sections of this paper when discussing those school districts.

The staffing for media centers in School District A is determined school-by-school, with no district model in place. Responsibilities for technology vary in each school. At the time of the study a few schools had professional instructional technology specialists, some had computer technicians, some shared technology personnel with other schools, and in some, the media specialist served as the technology specialist. School principals in District $\mathrm{A}$ are the primary decision-makers in regard to such staffing; however, some media specialists reported that site-based school advisory committees also have input.

School District B has a staffing model for their media centers. Each school has a professional media specialist (more than one in the larger schools), a media clerk, and a professional instructional technology specialist. The instructional media specialist serves not only the media center, but is also responsible for technology in the classrooms.

The district school media administrators in both districts were instrumental in arranging for the researcher to conduct the research and gain access to the media specialists. In District $\mathrm{A}$ the media specialists meet once (with the two professional district media supervisors present) on a regularly scheduled monthly basis during the afternoon of a school day. These meetings are arranged and conducted by the district supervisors. In addition to a business meeting and a short social time, some type of educational program is also planned. Often one or more of the district media supervisors are involved in the program. The programs frequently center on topics related to technology. The researcher administered an open-ended survey to 23 of the media specialists during one of these monthly meetings during the 1999-2000 school year. 
District B covers a larger geographic area than District A. For this reason media specialists meet in separate groups, according to their geographic placement in the district. A designated leader generally arranges the meeting but sometimes one or more of the four district media supervisors attends and shares information. Some of the groups meet during the afternoon of a school day while others meet after school. Formal programs are not usually a part of the meetings, and some of the groups do not seem to have regularly scheduled meetings. A few instructional technology specialists attend the meetings in District B, but the participants are primarily media specialists. The researcher administered the survey to 19 media specialists and 3 instructional technology specialists from two groups in the1999-2000 school year. District media supervisors are trying to encourage a larger attendance of the instructional technology specialists at these meetings. The researcher considered not including the surveys from the instructional technology specialists, but decided that the data are important to the study. In the "Demographics" discussion the responses of the instructional technology specialists are indicated when such designation seemed significant. In order to have an equal number of surveys administered in each district the researcher asked a media specialist from an additional group meeting to complete a survey. This questionnaire brought the total number of surveys in each district to 23 .

All surveys were completed anonymously. Participation was voluntary, but all media personnel in the meetings completed the surveys. Demographic information that was potentially significant to the study was requested on each survey.

\section{The Survey Instrument}

The survey instrument consisted of eight demographic questions: (1) the total years employed as a media specialist (or as an instructional technology specialist in District B); (2) years employed in the particular school district as a media specialist/instructional technology specialist; (3) grade level of the school served; (4) information relating to certification; (5) extent of responsibility for technology in the media center; (6) extent of responsibility for technology in the school; (7) representation on technology committees; and (8) sources of technology knowledge and skills. In addition, the media specialists were asked to respond to four broad open-ended questions dealing with the impact of technology on: (1) the school library media program; (2) the school library media collection; (3) the jobs of the school library media personnel; and (4) student learning in the school library media center.

\section{Demographic Information and Background of the Samples}

School District A has a student enrollment of just over 35,000, while enrollment in District $B$ is nearly 50,000. Both school districts have rural and urban areas, but neither contains large cities. Socioeconomic status and ethnic diversity are comparable in the two districts, with both factors represented over a wide range. School District A had a five-year sales tax plan during 1994-99 that provided over $\$ 40$ million for the purchase of technology equipment and software in the schools; no such taxes were collected in District $B$. In the past few years the emphasis in District B has been to provide media teams (consisting of media specialists, media clerks and instructional technology personnel) in all schools, in addition to adding technology hardware. Schools in District B are provided funds per student, and each school determines the manner in which the funds are utilized. 
When the researcher visited several schools in the two districts the disparity between the amount and newness of technology was apparent in most cases, although there were a few exceptions. The differences seemed most prominent in the elementary and middle schools. Schools visited in District A had much more and newer technology hardware, including both computer and video equipment. The TV production studios in District A were outstanding, particularly in the high schools. In the past several years there had been much emphasis on TV production and educational television in School District A. However, it is important to note that, in some of the District A schools, pieces of technology equipment (particularly computers) were sitting on tables or in boxes and were not yet operable. In one instance, 12 computers sat on tables in a media center for over a semester, waiting to be networked by a technology person who was assigned to more than one school. In another school, new television production equipment had not been set up for over a semester. The sole media specialist, along with a newly hired media clerk, were serving a student population of over 1300 students, and had been unable to find the time to get the television studio up and running.

\section{Grade Level}

Samples in both school districts included school media personnel serving in all school grade levels. In District A, 15 elementary, 2 middle school, and 6 high school media specialists responded to the survey. In District B, 8 elementary, 6 middle school, and 6 high school media specialists completed the survey. Additionally instructional technology specialists in 2 elementary and 1 middle school were a part of the study sample in District B. Grade levels of the schools served by the school media personnel did not appear to be significant.

\section{Certification}

In District A, 21 of the media specialists were certified in media by the state of Florida, 1 was working on obtaining media certification, and 1 was a paraprofessional, with no certification. In District B, 16 of the media specialists held Florida school media certification, and 4 media specialists were working on completion of the requirements for school media certification. One instructional technology specialist in District B was certified in home economics and 2 were certified in elementary education. Certification issues did not affect the findings of the study.

\section{Years of Experience}

Table 1 presents the samples' total years of experience as a library media specialist or instructional technology specialist. 
Table 1

Total Years of Experience as a Media Specialist

\begin{tabular}{ccr}
\hline Years of Experience & District A & District B \\
\hline Less than 1 & 2 & 1 \\
$1-5$ & 5 & $8 ; 2$ its* \\
$6-10$ & 6 & $2 ; 1$ its* \\
$11-15$ & 2 & 4 \\
$16-20$ & 3 & 0 \\
$21-25$ & 3 & 4 \\
$26-30$ & 0 & 0 \\
$30-35$ & 2 & 0 \\
\hline Total & 23 & 23 \\
\hline
\end{tabular}

*its=instructional technology specialist.

The table demonstrates that both school districts have a large number of media personnel (57\% in District A and $61 \%$ in District B) with 10 or less years of experience. In District A, $22 \%$ of the media specialists have over 20 years of experience in library media while in District B, $17 \%$ of the persons in the sample have more than 20 years media experience. It appears that both districts have been active in hiring newly trained media personnel and both will need to replace about one-fifth of their present media personnel in the next 5-10 years. However, both school districts are increasing rapidly in student population, with new schools being built each year; thus, an additional demand for school media personnel will exist.

\section{$\underline{\text { Responsibility for Technology }}$}

There was a noticeable difference in the technology responsibility held by media personnel in each of the school districts. These differences can be seen in Table 2.

\section{Table 2}

Number of Media Specialists Holding Responsibility for Technology

\begin{tabular}{lrrr}
\hline Setting for Technology Responsibility & District A & \multicolumn{1}{c}{ District B } \\
\hline Media Center-Total Responsibility & $18(78 \%)$ & $11(48 \%)$ \\
Media Center-Shared Responsibility & $4(17 \%)$ & $9 ; 3$ its* $(52 \%)$ \\
School-Total Responsibility & $10(43 \%)$ & 3 its* $(13 \%)$ \\
School-Shared Responsibility & $4(17 \%)$ & $4(17 \%)$ \\
\hline
\end{tabular}

*its=instructional technology specialist.

Notes: One media specialist in District A did not respond to the question dealing with technology responsibility in the media center. Some media specialists in both districts had no responsibility for technology outside of the media center. 
In District $A, 78 \%$ of the media specialists surveyed had total responsibility for technology in their media centers, compared to $48 \%$ in District B. In District A, $17 \%$ of the library media specialists had shared responsibility of technology in the media center, while in District B, $52 \%$ of the media personnel shared this responsibility.

In District $A, 43 \%$ of the school library media specialists had total technology responsibility for their schools, while $13 \%$ (all instructional technology specialists) had similar responsibilities in District B. No media specialists in District B felt total responsibility for technology in their schools. Shared technology responsibility for the school was reported by $17 \%$ of the library media specialists in both districts.

It appears that the differences in the staffing of media personnel in the two districts were significant in the assignment of technology responsibility. The media specialists in District A held more total responsibility for technology in both their media centers and in their schools.

\section{$\underline{\text { Representation on Technology Committees }}$}

Twenty-nine instances of representation on technology committees were reported by media personnel in District B, while 20 such instances were reported in District A. It is difficult to draw conclusions between the districts because the number of existing technology committees in each district was not known by the researcher. It does appear, however, that there is more technology committee representation in District B than in District A.

Table 3

Number of Media Specialists Serving on Technology-Related Committees

\begin{tabular}{lcr}
\hline \multicolumn{1}{c}{ Committees } & District A & District B \\
\hline School Technology & 17 & $18 ; 3$ its* \\
County Technology & 1 & 3 \\
WebPac & 0 & 1 \\
Accelerated Reader & 2 & 1 \\
Communications & 0 & 1 \\
Videoconferencing Manual & 0 & 1 \\
In-services & 0 & 1 \\
\hline Total & 20 & 29 \\
*its=instructional technology specialist. & & \\
Note: In some instances the same person served on more than one technology-related committee.
\end{tabular}

\section{Sources of Technology Knowledge of Skills}

School media personnel in both districts reported a large number of sources from which they obtained their technology knowledge and skills, as demonstrated in Table 4. Sources were ranked according to the number of times mentioned by the school library media personnel. 
Table 4

Sources of Technology Knowledge and Skills

\begin{tabular}{lcccc}
\hline \multicolumn{1}{c}{ Source } & District A & Rank & District B & Rank \\
\hline In-services & 15 & 1 & 14 & 2 \\
Self-Taught & 13 & 2 & 21 & 1 \\
LIS Courses & 7 & 3 & 9 & 3 \\
Conferences & 5 & 4 & 4 & 4 \\
Teachers/Other Media & 4 & 5 & 2 & 6 \\
Specialists & & & & \\
Technology Specialists & 2 & 6 & 4 & 5 \\
Manuals & 2 & 6 & 1 & 7 \\
Periodicals & 2 & 6 & 2 & 6 \\
Students & 1 & 7 & 1 & 7 \\
Observation & 0 & 0 & 1 & 7 \\
Company Tech Support & 0 & 0 & 1 & 7 \\
\hline Total & 51 & & 60 & \\
\hline
\end{tabular}

Note: Most persons listed more than one source.

In both school districts in-services and self-instruction ranked as the top two sources. It is apparent from the information reported in that these sources were by far the most important in both school districts. Courses in library science ranked third in both districts. Overall, rankings for sources of technology and skills were quite similar in both school districts and thus did not appear significant to the sampling or results of the study.

\section{Limitations of the Study}

The study sampled library media specialists in only two school districts in Florida. Although the findings cannot be generalized to all school systems, they can provide some insight into the impact of technology on school library media centers and the influence of staffing for technology responsibilities.

\section{Analysis of the Data}

After reading through the completed surveys, the researcher listed responses for each of the four broad areas of technology impact in two columns: District A and District B. The responses were placed into similar categories and counted. Total numbers of responses for each of the school districts plus a combined total for the districts were recorded. In some instances, where it appeared to be significant to the study, the researcher designated the comments as positive, negative, or neutral by analyzing both the content and tone of the responses. These totals, as well as individual descriptive responses, were used in the findings and implications of the study. 


\section{FINDINGS}

The findings for this study are discussed in relation to the four research questions of the study: How has technology made an impact on: (1) school library media programs, (2) school library media collections, (3) jobs of the personnel working in the media center, and (4) student learning in the media center? Since the researcher was also interested in how staffing in the media centers affected the responses, comparisons and contrasts in the responses of media personnel in the two districts are also discussed. When demographics of the samples appear to be significant they are noted.

\section{Impact of Technology on the School Library Media Programs}

In both school districts the school media personnel reported that technology had made the most impact on the number of resources and access to those resources for both students and teachers. All responses were positive.

\section{Table 5}

\section{Top-Ranking Responses Dealing with the Impact of Technology on Programs}

\begin{tabular}{lcccc}
\hline \multicolumn{1}{c}{ Responses } & District A & Rank & District B & Rank \\
\hline Resources & 13 & 1 & 15 & 1 \\
Management of Media & 9 & 2 & 12 & 2 \\
Physical Space & 3 & 3 & 2 & \\
Teaching Tool & 3 & 3 & 4 & 4 \\
Center of School & 1 & & 7 & 3 \\
Other Responses & 2 & & 11 & \\
\hline Total & 31 & & 51 & \\
\hline
\end{tabular}

Thirteen media specialists in District A mentioned the impact of technology relating to resources, while 15 media personnel made similar responses in District B. Typical responses included:

- Provides students with additional resources for retrieving information.

- Information is more organized and easily accessed.

- Online research programs give students and teachers unlimited information sources that are current and easy to access.

Management of media (cataloging, circulation, collection development, and inventory) was ranked second in technology impact on school library media centers. Twelve media personnel in District B and 9 in District A mentioned these management functions. Again, the comments were positive. Responses included:

- Increased efficiency in collection development.

- It has made it easier to check books in and out. Keeps track of overdues.

- Using the automated system saves time. 
- There's been a big change in methods of storage, check out, searching for titles, and inventory.

Seven media personnel in District B mentioned that technology had made the media center the center of the school, while only one media specialist in District A made a similar response by stating "technology has made the media center vital to the school." Other responses mentioned by more than three persons were that the media specialist uses technology to teach and that technology reduces the physical space for other resources and functions.

There were 31 responses to this question in District $A$ and 51 in District B. Combining responses in both districts, the total number of comments about the impact of technology on media center programs was 82 .

\section{Impact of Technology on Collections}

While the responses dealing with the impact of technology on media programs were fairly similar in the two school districts, this was not the case in the responses about the influence of technology on collections in the media centers. Thirty-eight responses in this category were made by media specialists in District A, while media personnel in District B made 48 comments related to the impact of technology on collections.

\section{Table 6}

\section{Top-Ranking Responses Dealing with the Impact of Technology on Collections}

\begin{tabular}{lcccc}
\hline \multicolumn{1}{c}{ Responses } & District A & Rank & District B & Rank \\
\hline Easier Accessibility & 9 & 1 & 3 & \\
Collection Development & 7 & 2 & 4 & 5 \\
Electronic Reading & 5 & 3 & 7 & 3 \\
Programs & 5 & 3 & 13 & 1 \\
Balancing of Formats & 5 & 3 & 2 & \\
Availability of New Formats & 2 & & 9 & 2 \\
Equipment & 0 & & 6 & 4 \\
Interlibrary Loans & 5 & & 4 & \\
Other Responses & 38 & & 48 & \\
\hline Total & & & & \\
\hline
\end{tabular}

District A responses most frequently dealt with easier access to the collection and improved means of collection development--particularly being able to order online. In District B trying to balance the formats and finding funds for print materials because of the added budget item needed for technology was mentioned the most often by the media personnel, followed by comments dealing with old equipment needing replacing or updating. Some responses simply stated facts, while others reflected concern:

- A large percent of the budget now goes to videos, CDs, CD-ROMs, software, and the equipment necessary for such products. 
- Sometimes the budget doesn't go far enough and it's hard to replenish the books.

- I am in the process of replacing the classroom TVs. It is an expensive proposition. Those purchases made a $\$ 1600$ dent in money I had allocated for new library books.

- Money now has to be divided between technology and print. Decisions must be made on where the priorities lie.

- Some of the old equipment is still in use, but newer equipment to deal with new technology demands need to be included.

- The old computers are not helpful.

- The technology costs lots more money! The constant changes and updates needed for the equipment are "forever."

The opportunities for more interlibrary loan were mentioned by six school library media specialists in District B, but not at all in District A. Some of the responses in District B were:

- Our district's public access catalog makes it easy to see what other media centers have in their collection and patrons can borrow materials from other schools and other counties in the state.

- Interlibrary loan helps supply resources and it is so easy to handle the ILLs.

Five responses in District $A$ dealt with the positive aspects of being able to provide new formats, while this category was not ranked in the top five in District B. Some responses in District $\mathrm{A}$ dealing with formats included:

- New media has replaced old.

- More formats available for student papers and reports.

Between the two districts, however, there was one similar category ranking. Both districts placed electronic reading programs (most often the Accelerated Reader) third in the impact of technology on the collection. Most responses dealing with the electronic reading programs were neutral in tone, simply stating the impact:

- We have ordered books simply because there are AR disks for them.

- $\mathrm{AR}$ has had a huge impact. Much of our budget is being spent on buying books for this program.

- The collection highly reflects AR materials needed for testing in the classrooms.

\section{Impact of Technology on Jobs of Media Personnel}

Responses of the impact of technology on the jobs of the media personnel were also quite different in the two school districts, particularly in the number of negative comments expressed. The school media specialists in District A expressed many more negative feelings about technology in relation to their jobs than those in District B. 
Table 7

Top-Ranking Responses Dealing with the Impact of Technology on Jobs of Media Personnel

\begin{tabular}{|c|c|c|c|c|c|c|c|c|c|c|}
\hline Responses & $\underline{\text { District A }}$ & \pm & $=$ & neu & $\underline{\text { Rank }}$ & District B & \pm & $=$ & neu & $\underline{\text { Rank }}$ \\
\hline Time/Responsibility & 22 & 1 & 21 & 0 & 1 & 19 & 3 & 14 & 2 & 1 \\
\hline Learning/Knowledge & 8 & 1 & 5 & 2 & 2 & 9 & 3 & 3 & 3 & 2 \\
\hline Other Staff & 4 & 0 & 4 & 0 & 3 & 5 & 5 & 0 & 0 & 4 \\
\hline Efficiency & 2 & 2 & 0 & 0 & 4 & 4 & 4 & 0 & 0 & 3 \\
\hline Other Responses & 6 & 1 & 3 & 2 & & 8 & 6 & 1 & 1 & \\
\hline Total & 42 & & & & & 45 & & & & \\
\hline
\end{tabular}

In District A there were 42 responses dealing with the impact of technology on the jobs of the school media specialists. Of these responses, 33 were negative, 5 were positive, and 4 were neutral. The concept of time ranked first ( 22 responses) by a large margin. Comments mentioning the learning curve and knowledge related to technology ranked second, and comments about other staff ranked third. Responses about time in District A included:

- Too much to do, not enough time.

- This should make life easier but instead I work longer hours.

- Much more time spent on assisting students in the use of computer programs, how to print, how to research topics "online," more policing of the use of computer resources.

- You're now dealing with equipment breakdowns and at times not serving your students.

- It is impossible to do my job as media specialist and technology specialist and do a good job with either one.

- We do more in the same amount of time.

Some of the comments relating to the learning curve involved with technology were:

- I did not think in the beginning I would ever feel comfortable using a PC and the Follett system, but it has happened! I believe in miracles.

- I am busier than ever trying to stay ahead of this ever-changing field.

- We need more technical training.

Staff-related responses (all negative) included:

- More personnel are needed.

- I have a part-time aide but we are doing three persons' jobs.

In District $B$ there were only a few more responses to this question than in District $A$. In District $\mathrm{B}, 45$ comments were made about the impact of technology on media personnel 
jobs. However, the responses were fairly equal in tone with 21 positive comments, 18 negative comments, and 6 neutral. Time-related and responsibility comments ranked first (19 responses-3 positive, 14 negative, and 2 neutral), while comments related to technology knowledge ranked second ( 9 responses -3 positive, 3 negative, and 3 neutral). Comments about having another staff member to help with technology were mentioned by 5 (all positive responses) media persons, while 4 media personnel made responses related to efficiency (all positive).

Comments about the relationship of time and technology in the media jobs included:

- Because of the high numbers of students using the media center, media personnel seldom sit down. The computers freeze, printers don't print, keyboards don't work —oh so many things can go wrong - and you have to be right there to fix all the problems.

- The emphasis has changed from "educator" to Mr. Fix it!

- It has become a major portion of my job since becoming a media specialist. I spend a good portion of my time teaching students and faculty to take advantage of the technology available to them for research and production.

- Since I have been a media specialist for a short time, I did not experience the technical revolution as a media specialist, but I believe that technology frees up considerable time to interact with students rather than process books and keep records.

Some comments about knowledge were:

- It has made it a requirement to have a good grasp of computers and how they work.

- We have become knowledgeable with technology.

- We are expected to be omniscient and do it all.

- This is not a job that you learn and then you are finished. We continue to learn and teach new technology and new resources. The job is never boring. We are also learning that sometimes our students are our best teachers.

Responses indicating an effect on efficiency included:

- We can do our job more efficiently and quickly.

- It helps us to be better organized and more efficient.

And finally, some of the responses relating to other media personnel were:

- It has affected us also because the "amount" of technology allowed us to have a specialist for technology, which caused our almost "burn-out" to be "put out"!

- Technology is directly responsible for my position. Without technology there would not be a need for a tech specialist (response by a instructional technology specialist).

- Team commitment-media and tech working together makes a well-rounded program. 
- It has given me a team player (tech specialist) to work with. I used to feel like I was the only person in the school that understood how I felt. Now I have someone that I can relate to. We can support each other.

Combining both districts there were a total of 87 comments made regarding the impact of technology on jobs.

\section{Impact of Technology on Student Learning in Media Centers}

In both school districts there were numerous positive comments relating to the impact of technology on student learning in school media centers. District A media specialists made 35 responses to this question ( 29 positive, 6 negative, and 2 neutral), while in District $B$ the media personnel made 59 comments ( 42 positive, 14 negative, and 3 neutral). Responses in this category were generally longer and more descriptive than for the other questions. Table 8 shows the responses that ranked highest in both school districts.

\section{Table 8}

\section{Top-Ranking Responses Dealing with the Impact of Technology on Student Learning in School Media Centers}

\begin{tabular}{|c|c|c|c|c|c|c|c|c|c|c|}
\hline Responses & District A & \pm & $=$ & neu & $\underline{\text { Rank }}$ & District B & \pm & $=$ & neu & $\underline{\text { Rank }}$ \\
\hline $\begin{array}{l}\text { Formats/Learning } \\
\text { Styles }\end{array}$ & 11 & 11 & 0 & 0 & 1 & 23 & 23 & 0 & 0 & 1 \\
\hline $\begin{array}{l}\text { Students' Special } \\
\text { Liking }\end{array}$ & 10 & 10 & 0 & 0 & 2 & 13 & 13 & 0 & 0 & 3 \\
\hline $\begin{array}{l}\text { Critical Thinking } \\
\text { Skills }\end{array}$ & 8 & 4 & 4 & 0 & 3 & 15 & 5 & 10 & 0 & 2 \\
\hline Currency of Formats & 4 & 4 & 0 & 0 & 4 & 2 & 2 & 0 & 0 & \\
\hline Other Responses & 4 & 0 & 2 & 2 & & 6 & 0 & 3 & 3 & \\
\hline Total & 37 & & & & & 59 & & & & \\
\hline
\end{tabular}

$+=$ positive comments. - = negative comments. neu $=$ neutral comments.

The availability of more formats to accommodate for a variety of learning styles ranked first in both school districts, with 11 comments (all positive) in District $A$ and 23 (all positive) in District B. In District A students' special liking for technology ranked second with 10 responses (all positive), while District B media personnel mentioned this in 13 cases (all positive), with a rank of third place. Comments related to critical thinking skills ranked second in District B (15 responses- 5 positive and 10 negative) and third in District A (8 responses-4 positive and 4 negative). Four media specialists in District A commented on the positive contribution of the currency of technology formats (ranking fourth) while in District B only 2 media personnel made similar responses.

Among the comments expressed by the media personnel in regard to the availability of information in various formats and being able to accommodate different student learning styles were the following:

- Variety of learning modes for various learning styles. 
- It has opened up new avenues in alternative assessment and teaching styles. With the abundance of technology available to students and faculty, accommodating different learning styles is easier than ever.

- Students are able to demonstrate their learning in many ways unavailable before. For example by producing video presentations, web pages, newspapers, and slide shows.

- Technology has given students more ways in which to express themselves, to prove what they have learned, and to use the media center.

The excitement and interest that students have when working with technology was related by several of the media specialists:

- Students seem totally comfortable with all the computers and can hardly wait for the opportunity to produce/star/direct the morning news shows.

- It seems that students are more willing to do online research. They also enjoy being able to print the results of their searches, rather than having to write everything down.

- Students seem to be more excited about learning when they can use the computers. When they realize they need more information to finish a report, they keep that enthusiasm in comparison to when using those "dreaded books."

- Increased interest. Technology pulls them in-then we catch them.

- They love using equipment-all—computers, videos, whatever.

Comments relating to critical thinking and information literacy skills were both positive and negative:

- Learning to evaluate information and choosing appropriate resources for information and for production helps sharpen students' critical thinking skills and problem solving.

- Requires students to be more efficient/effective at using/evaluating information.

- I think it has affected them negatively in a lot of cases. They take too much time looking up useless information on Internet instead of using more appropriate books.

- There is a tendency to print out and copy rather than analyze information. Critical thinking is a major concern.

- In some cases technology has been used just for the "bells and whistles" effect. This serves no purpose.

- Gradually they lose the ability to use indexes, etc. because keyword searching is so easy.

The opportunity for students to be exposed to more current information using technology was also mentioned by some of the media specialists:

- Internet provides the most current information-not old stuff.

- Much more current information available on CD or online. 
Combining the responses in both districts, this category received a total of 96 comments- 37 in District A and 59 in District B.

\section{IMPLICATIONS}

Media personnel in both districts see the emerging technologies as having a positive effect on their programs by providing resources in a variety of formats that are easily accessible. The contributions that technology has made in the management of media centers, including such activities as circulation, cataloging, and inventory, are also viewed as important benefits.

The philosophy of the importance of having school library media centers serve as the "hub of the school" has been widely accepted for many years in school librarianship. In the 1990 s in the United States many state and district media supervisors were encouraging media specialists to embrace technology and volunteer to be the school's technology specialist in order to strengthen this philosophy. Yet it is interesting to note that only one media specialist in District A saw technology as a contributing factor in making the facility the center of the school and the school's curriculum. Perhaps more media personnel in District B saw their facilities and programs as the center of the school because they had team members who could assist them in planning and implementing collaborative activities with classroom teachers. It appears that in District B more thought and planning had been put into the total environment of the media center as it relates to technology.

Although media specialists in both districts reported some difficulty in finding the funds to balance the print and non-print formats in their media centers this feeling was much more predominant in the responses of the media personnel in District B. A similar situation existed in the comments dealing with the replacement and updating of equipment. The extra funds provided for technology through taxes in District $A$ is the most likely explanation for this finding.

Media specialists in both districts experienced the impact of electronic reading programs, such as the Accelerated Reader, on their collections. This is an area that might warrant further investigation.

Another interesting finding from the study deals with the impact of interlibrary loans on the collection. While this was positively commented on by 6 media personnel in District $B$, no one mentioned it in District A. One might conclude that District B had a more formalized and efficient method of providing interlibrary loan than was present in District $A$, thus adding to accessibility for its patrons.

The other category that indicated fairly large differences between the two school districts was the impact of technology on jobs of media personnel. While media specialists in both districts indicated they experienced difficulties in meeting all their job responsibilities with the introduction of new technologies, District A media specialists expressed more overall dissatisfaction and frustration about the effects that technology had on their positions. The conclusion from this finding is that several media specialists in District A were not receiving the helpful assistance in technology that was being provided by the instructional technology specialists in District B. It is also important to note, however, that despite the team approach and technical assistance provided in District $\mathrm{B}$, there were 
several media specialists who, because of technology, still expressed difficulty in meeting all the responsibilities of their positions. One might conclude that, like media specialists in the Georgia study (Meghabghab \& Price) roles of the media specialist and technology specialist have not been clearly defined, and responsibilities are converging. Another explanation might simply be that the tasks involved with technology are growing so rapidly that the numbers of personnel responsible for technology in District B are simply not sufficient. This is an area that deserves more research and investigation.

In both districts media personnel were seeing the positive effects of technology on providing more information formats to accommodate for a variety of student learning styles. All media specialists also recognized and affirmed the enthusiasm and interest shown by students as they used technology for learning activities. Mixed feelings and concern, however, was evident in the area of students' critical thinking skills. Time, personnel, and training to teach the importance of these skills, both in the media center and in the classroom, are essential in order for technology to have a positive effect on student learning.

A last area of interest is the total number of responses given by media personnel in both school districts as demonstrated in Table 9.

Table 9

Total Reponses on the Open-Ended Questionnaire

\begin{tabular}{lcccc}
\hline \multicolumn{1}{r}{ Category } & District A & & District B & Total \\
\hline Programs & 31 & 51 & 82 \\
Collections & 38 & 48 & 86 \\
Jobs & 42 & 45 & 87 \\
Student Learning & 37 & 59 & 96 \\
\hline Total & 148 & 203 & 351 \\
\hline
\end{tabular}

Except for the category dealing with the impact of technology on jobs, there seemed to be significantly more responses made by the media specialists in District B than in District A. The researcher was interested in this finding since media specialists in both districts were provided equal amounts of time to respond to the questionnaire and no time pressure was put on the media personnel by the researcher, district media supervisors, or persons conducting the meetings where the questionnaires were administered. The researcher examined the demographic information on the surveys in District A where very brief or no responses to categories were expressed; however, no demographic information seemed to correlate with surveys with brief or no responses in categories. Thus, one might conclude that due to their planning and implementation of a model to help deal with technology in District B media personnel had already put much thought into how technology was impacting their programs and facilities. It 2 peared that many more of the media specialists in District B were actively involved with other staff personnel in activities to integrate technology into their programs and into the school curriculum and thus they were considering technology issues on a daily basis. 
Using the responses of the media personnel in both school districts the researcher has developed additional specific questions that are being asked in both interviews and focus groups. Those responses are being gathered to assist in the validation of the responses received in the open-ended questionnaires and to provide more depth to the study.

\section{CONCLUSION}

Both school districts in this study have been taking active roles into integrating technology into their media centers-District A through the provision of extra technology funding and District $B$ through planning team models and the provision of personnel. Yet both districts continue to be challenged in this area, and some media specialists continue to be unable to keep up with the added responsibilities or the learning curve presented by the new technologies. Finding the appropriate balance between providing funds for hardware and for personnel is one of the answers to the problem of how to best integrate technology into the media center, but attention must also be paid to defining the roles of team players and providing ongoing training to media personnel to help them meet the demands of the technology learning curve. It is evident that media personnel and media centers are well on their way to contributing positively to student learning through the use of technology. Hopefully, studies such as this one will help school personnel plan as they use the media center and media personnel to be instrumental in this process and to truly serve as the "learning center" of the school.

\section{REFERENCES}

Balancing act-survey results, part I. (1999). The School Librarian's Workshop, 20 (1), 4-6. Balancing act-survey results, part II. (1999). The School Librarian's Workshop, 20 (2), 11 12.

Bruns, L. (1997). Texas Public School library media specialists' perceptions of the use of the Internet in their schools. (University of North Texas). Dissertations Abstracts International, $58,2510 \mathrm{~A}$.

Everhart, N. (1990). An analysis of the work activities of high school library media specialists in automated and nonautomated library media centers using work sampling.

(Doctoral dissertation, Florida State University). Dissertations Abstracts International, 51, 3938A.

Meghabghab, D. \& Price, C. (1997). The impact of a technology-rich environment. (ERIC Document Reproduction Services No. ED 412 953).

Powell, D. J. (1998). Utilization levels and attitudes toward technology in Tennessee School Library Media Centers. (The University of Memphis). Dissertations Abstracts International, 59, 3415A.

Weeks, A. C. (1982). A study of the attitudes of New York State School Library Media Specialists Concerning Library Networking and Technology. (University of Pittsburgh). Dissertations Abstracts International, 43, 2819A.

Zimmerman, N. (1992). A study of the attitudes of building-level school library media specialists in New York State toward multitype library networking and technology. (Texas Woman's University). Dissertations Abstracts International, 54, 0015A. 